\title{
Perilaku gizi dan hidrasi selama kehamilan berhubungan dengan konstipasi
}

\author{
Khairizka Citra Palupi*, Mertien Sa'pang, Erry Yudhya Mulyani, Aditya Fatkhi Laili
}

\begin{abstract}
Background: Prevalence of constipation in pregnant women is estimated at 11-38\%. Impact of constipation in pregnant women are haemorrhoids and decreased quality of life. Meanwhile, determinants known to influence constipation during pregnancy are hormonal changes, poor diet, low physical activity and lack of fluid consumption.

Objectives: Identify the determining factors that can affect occurrence of constipation and investigated the difference based on constipation status among pregnant women in Public Health Centre in Jakarta, Indonesia;

Methods: This research was a cross sectional design conducted in July 2019 to October 2019. The subject was pregnant women. We used accidental sampling method to recruit subjects in Public Health Centre, Kebun Jeruk, West Jakarta. We measured the determining factors of constipation among pregnant women. Characteristic of pregnant women, knowledge, attitudes and practices were measured by questionnaires. Anthropometrics data for weight, height, and mid arm circumference were measured. Haemoglobin level was also measured. Bivariate analysis using Pearson or Spearman was used to investigate which factors associated significantly with constipation among pregnant women. We also assessed the difference of characteristic of pregnant women, knowledge, attitudes and practices using differential analysis (Mann-Whitney U-test).

Results: The results showed that prevalence of constipation was 30\%. Differential analysis showed that mothers who experienced constipation had a younger age and low nutritional and hydration behaviour scores. Other variables such as gestational age, weight before pregnancy, upper arm circumference, height, haemoglobin, knowledge score and nutritional attitude and hydration did not show significant differences based on constipation status. Correlation analysis showed an inverse relationship between maternal age and incidence of constipation, with $r=0.242$ and a $p$-value $=0.015$. Maternal age, nutritional behaviour and hydration also showed significant inverse relationship with incidence of constipation $(r=-0.206$ and $p$-value 0.039);
\end{abstract}

Conclusion: Nutritional and hydration behaviour during pregnancy was related to the occurrence of constipation. Mothers are advised to have good nutrition and hydration behaviour to prevent constipation.

Keywords: constipation; pregnant women; public health center

\begin{abstract}
ABSTRAK
Latar Belakang: Prevalensi konstipasi pada wanita hamil diperkirakan 11-38\%. Dampak konstipasi pada ibu hamil adalah hemoroid dan penurunan kualitas hidup. Sementara itu, faktor determinan yang diketahui mempengaruhi konstipasi selama kehamilan adalah perubahan hormon, pola makan yang buruk, aktivitas fisik yang rendah dan konsumsi cairan yang kurang.

Tujuan: Mengidentifikasi faktor determinan yang bisa mempengaruhi kejadian konstipasi pada ibu hamil and menginvetigasi perbedaan status konstipasi diantara ibu hamil di Puskesmas di Jakarta.

Metode: Penelitian ini menggunakan desain cross sectional yang dilakukan pada Juli 2019 sampai dengan Oktober 2019. Kita menggunakan metode accidental sampling untuk merekrut subjek di Puskesmas Kebun Jeruk, Jakarta Barat. Kita mengukur faktor-faktor yang menentukan kejadian konstipasi diantara ibu hamil. Karakteristik ibu hamil, pengetahuan, sikap dan perilaku diukur menggunakan kuesioner. Data antropometri seperti berat badan, tinggi badan, dan lingkar lengan atas juga diukur. Kadar hemoglobin juga diukur. Analisis bivariat menggunakan Pearson atau Spearman digunakan untuk menginvestigasi faktor yang dihubungkan secara signifikan dengan konstipasi pada ibu hamil. Kita juga mengkaji perbedaan karakteristik ibu hamil, pengetahuan, sikap dan perilaku menggunakan uji beda (Mann-Whitney U-Test).

Hasil: Hasil penelitian menunjukkan prevalensi konstipasi sebesar 30\%. Berdasarkan kejadian konstipasi, Ibu yang mengalami konstipasi memiliki usia yang lebih muda dan skor perilaku gizi dan hidrasi yang rendah.. Variabel yang lain seperti umur kehamilan, berat badan sebelum hamil, lingkar lengan atas, tinggi badan, hemoglobin, skor pengetahuan dan sikap gizi dan hidrasi tidak menunjukkan perbedaan yang signifikan antara ibu yang mengalami konstipasi dan tidak mengalami konstipasi. Analisis korelasi menunjukkan hubungan berkebalikan antara usia ibu dan kejadian konstipasi dengan $r=0.242$ and a p-value $=0.015$. Usia ibu, perilaku gizi dan hidrasi juga menunjukkan hubungan berkebalikan yang signifikan dengan kejadian konstipasi ( $r=-0.206$ and p-value 0.039);

Simpulan: Perilaku gizi dan hidrasi selama kehamilan berhubungan dengan kejadian konstipasi. Ibu disarankan memiliki perilaku gizi dan hidrasi yang baik untuk mencegah konstipasi.
\end{abstract}

Kata Kunci : konstipasi; ibu hamil; puskesmas

Jurusan Ilmu Gizi Fakultas Ilmu Kesehatan Universitas Esa Unggul. Jl. Arjuna Utara 9, Kebon Jeruk, Jakarta Barat, DKI Jakarta, Indonesia

*Korespondensi : E-mail: khairizka.citra@esaunggul.ac.id 


\section{PENDAHULUAN}

Konstipasi adalah masalah kesehatan umum di dunia. Penurunan defekasi dan feses yang keras adalah manifestasi utama konstipasi. ${ }^{1}$ Risiko konstipasi pada wanita lebih tinggi dibandingkan laki-laki $2: 1^{2}$ Kondisi kehamilan pada wanita, juga meningkatkan risiko konstipasi. Prevalensi konstipasi pada wanita hamil diperkirakan 11-38\%. ${ }^{3}$ Penelitian menunjukkan bahwa prevalensi konstipasi fungsional bervariasi antara trimester 1 dan 2 dengan kisaran 35\% dan 39\%, dan $21 \%$ pada trimester $3 .{ }^{4}$ Dampak konstipasi pada ibu hamil jika tidak diatasi adalah hemoroid dan penurunan kualitas hidup. ${ }^{5}$

Banyak studi telah melaporkan bahwa usia, jenis kelamin, status sosial ekonomi, kebiasaan makan, tingkat pendidikan, tingkat kecemasan, depresi dan faktor psikologis lainnya telah dihubungkan dengan kejadian konstipasi fungsional pada berbagai populasi. ${ }^{6-16}$ Sementara itu, faktor determinan yang diketahui mempengaruhi konstipasi selama kehamilan adalah usia, indeks massa tubuh sebelum kehamilan, jenis pekerjaan, konsumsi sayur dan buah, kondisi psikologis, riwayat konstipasi sebelum kehamilan, perubahan hormon, asupan serat, aktivitas fisik yang rendah, konsumsi cairan yang kurang.7,17-18 Perubahan kerja hormon endokrin semasa kehamilan seperti peningkatan kadar progesterone mampu memicu hipomotilitas pada usus besar ibu hamil selama trimester 2 dan 3, sehingga kondisi ini memicu relaksasi dari otot polos di usus yang selanjutnya meningkatkan risiko konstipasi semasa kehamilan. ${ }^{3,7}$

Sejauh ini, penelitian faktor determinan konstipasi pada ibu hamil di Indonesia hanya terbatas pada asupan serat, cairan, konsumsi tablet besi, dan aktivitas fisik. ${ }^{19-}$ ${ }^{20}$ Masih belum ada penelitian yang menghubungkan data antropometri, status anemia, tingkat pengetahuan, sikap dan perilaku gizi dan hidrasi pada kejadian konstipasi semasa kehamilan. Antropometri, status anemia dan tingkat pengetahuan, sikap dan perilaku gizi dan hidrasi perlu dikaji untuk mengidentifikasi lebih lanjut etiologi mendasar dari kejadian konstipasi pada ibu hamil dan membuat model intervensi yang tepat. Beberapa penelitian di Indonesia masih menunjukkan hubungan antara tingkat pengetahuan ibu dengan kejadian anemia dan status gizi. ${ }^{21,22}$ Oleh karena itu, peneliti tertarik untuk menganalisis faktor determinan kejadian konstipasi pada ibu hamil di Puskesmas Kebon Jeruk Jakarta Barat serta mengidentifikasi perbedaan faktorfaktor tersebut berdasarkan status konstipasi ibu hamil. Jumlah ibu hamil yang mengunjungi Puskesmas Kebon Jeruk, Jakarta Barat, DKI Jakarta cukup banyak yaitu sekitar 5774 orang per bulan. Tingginya jumlah ibu hamil yang berkunjung ke Puskesmas Kebon Jeruk perlu mendapat perhatian karena kehamilan merupakan jendela peluang untuk memperbaiki generasi dan membentuk generasi unggul.

\section{BAHAN DAN METODE}

Penelitian ini menggunakan desain cross sectional yang akan dilakukan pada Mei - September 2019. Lokasi penelitian dilakukan di wilayah kerja Puskesmas Kecamatan Kebon Jeruk, Jakarta Barat dengan kriteria daerah padat penduduk dengan pelayanan poli kebidanan yang paling banyak (120 - 150 ibu hamil per hari). Penelitian ini telah sudah lolos kaji etik Universitas Esa Unggul dengan nomor 0119-19.114/DPKEKEP/FINAL-EA/UEU/V/2019.

Populasi pada penelitian ini ialah ibu hamil yang memeriksakan kehamilannya di Puskesmas Kecamatan Kebon Jeruk sejak trimester pertama. Adapun kriteria inklusi sampel sebagai berikut yaitu Ibu hamil yang memeriksakan kandungannya di Puskesmas Kecamatan Kebon Jeruk, sehat, usia ibu $>18$ - 35 tahun, tinggi badan ibu 150 - $165 \mathrm{~cm}$, IMT 18,5 - 25,00, mendapatkan penjelasan penelitian dan menyetujui informed consent, bersedia untuk mematuhi prosedur penelitian. Sementara untuk kriteria eksklusi adalah ibu hamil yang menderita penyakit infeksi sekunder berdasarkan hasil pemeriksaan dokter dan pernah melahirkan BBLR dan bayi pendek $(<48 \mathrm{~cm})$.

Data yang terkumpul dalam penelitian ini yaitu karakteristik subjek, data laboratorium (hemoglobin), data antropometri (berat badan, tinggi badan, lingkar lengan atas), dan data pengetahuan, sikap dan perilaku gizi dan hidrasi ibu hamil. Pengukuran antropometri dilakukan oleh enumerator terlatih dan bidan. Alat bantu pengukuran berat badan dengan timbangan berat badan digital merk Omron $(0,1 \mathrm{~kg})$, mikrotoa untuk tinggi badan $(0,1 \mathrm{~cm})$, meterline untuk lingkar lengan atas $(0,1$ $\mathrm{cm})$. Pengukuran laboratorium untuk kadar haemoglobin di ambil oleh tenaga phlebotomi terlatih dan diperiksa di laboratorium terakreditasi. Pengambilan darah lengkap dilakukan sewaktu, sesaat sebelum pemeriksaan kehamilan di ruang KIA. Haemoglobin diperiksa dengan menggunakan alat Haemometer. Data pengetahuan, sikap dan perilaku tentang gizi dan hidrasi di peroleh melalui wawancara ibu hamil oleh enumerator terlatih setelah dilakukan pemeriksaan rutin kehamilan di ruang KIA. Wawancara dilakukan selama 15-20 menit mulai dari proses pencairan (perkenalan) hingga menjawab pertanyaan seputar gizi dan hidrasi. Adapun point pertanyaan terkait gizi dan hidrasi kehamilan untuk pengetahuan berjumlah 10 butir, sikap 5 butir dan perilaku 5 butir. Instrumen ini telah di gunakan dalam penelitian sebelumnya tentang hidrasi kehamilan. ${ }^{23}$ Status Konstipasi diukur menggunakan Kriteria Roma III untuk konstipasi fungsioanal. ${ }^{24}$

Analisis data menggnakan software SPSS versi 21.0 for Windows. Analisa deskriptif dilakukan berupa 
distribusi frekuensi dan persen $(\mathrm{n}, \%)$ untuk rataan dan simpangan baku untuk data numerik. Analisis inferensial yang digunakan ialah uji korelasi Pearson Product Moment untuk data normal atau Spearman untuk data tidak normal. Selain uji korelasi kami juga menggunakan uji beda menggunakan Mann-Whitney U-test. Uji dinyatakan bermakna jika p-value $<0.05$.

\section{HASIL}

\section{Karakteristik Umum Responden}

Subjek dalam penelitian ini berjumlah 100 orang ibu hamil. Prevalensi konstipasi sebesar 30\% ( $\mathrm{n}=30$ orang). Tabel 1 menunjukkan karakteristik umum responden berdasarkan umur ibu, umur kehamilan, lingkar lengan atas, berat badan sebelum hamil, tinggi badan, hemoglobin, skor pengetahuan, sikap dan perilaku gizi serta hidrasi. Median umur ibu saat hamil yaitu 27 tahun yang merupakan usia reproduksi. Median umur kehamilan yaitu di trimester 2 (28 bulan). Rerata lingkar lengan atas cukup melebihi normal yaitu 26,86 $\mathrm{cm}$. Rerata kadar $\mathrm{Hb}$ masih normal namun mendekati batas bawah normal yaitu $11.79 \mathrm{mg} / \mathrm{dl}$. Untuk skor pengetahuan rerata masih rendah yaitu 68.86, skor sikap gizi dan hidrasi baik yaitu 88.34 dan skor perilaku gizi dan hidrasi sedang yaitu 79.67 .

\section{Karakteristik Responden Berdasarkan Kejadian Konstipasi}

Berdasarkan kejadian konstipasi, maka ibu yang mengalami konstipasi memiliki usia yang lebih muda dan skor perilaku gizi dan hidrasi lebih. Sementara untuk variabel yang lain seperti umur kehamilan, berat badan sebelum hamil, lingkar lengan atas, tinggi badan, hemoglobin, skor pengetahuan dan sikap gizi dan hidrasi tidak menunjukkan perbedaan yang signifikan ketika dianalisis menggunakan Mann-Whitney U-test (Tabel 2).

Tabel 1. Karakteristik Responden

\begin{tabular}{lcc}
\hline \multicolumn{1}{c}{ Variabel } & Mean/Median + SD & Min-Max \\
\hline Umur Ibu (tahun) & $27,00 \pm 5.33$ & $18.00-39.00$ \\
Umur Kehamilan (bulan) & $28,00 \pm 9.37$ & $2.00-29.00$ \\
Berat Badan Sebelum Hamil (kg) & $53,94 \pm 9,44$ & $40.00-85.00$ \\
Lingkar Lengan Atas (cm) & $26,86 \pm 5,09$ & $21.00-65.00$ \\
Tinggi Badan (cm) & $154,66 \pm 5,67$ & $134.00-170.00$ \\
Hemoglobin (mg/dl) & $11,79 \pm 1,09$ & $8.90-14.70$ \\
Skor Pengetahuan & $68,86 \pm 14,18$ & $33.30-100.00$ \\
Skor Sikap Gizi dan Hidrasi & $88,34 \pm 6,85$ & $66.70-100.00$ \\
Skor Perilaku Gizi dan Hidrasi & $79,67 \pm 11,27$ & $53.30-100.00$ \\
\hline
\end{tabular}

Tabel 2. Karakteristik Responden Berdasarkan Kejadian Konstipasi

\begin{tabular}{lcc}
\hline \multicolumn{1}{c}{ Variabel } & Konstipasi & Tidak Konstipasi \\
\hline Umur Ibu (tahun) & $25.5(18-34)^{*}$ & $27(18-39)$ \\
Umur Kehamilan (bulan) & $28(5-39)$ & $29,5(2-38)$ \\
Berat Badan Sebelum Hamil (kg) & $53.96(11.06)$ & $53.92(8.74)$ \\
Lingkar Lengan Atas (cm) & $27.08(4.20)$ & $26.77(5.46)$ \\
Tinggi Badan (cm) & $154.10(6.57)$ & $154.9(5.27)$ \\
Hemoglobin (mg/dl) & $11.79(0.99)$ & $11.79(1.13)$ \\
Skor Pengetahuan & $72.89(13.66)$ & $67.14(14.14)$ \\
Skor Sikap Gizi dan Hidrasi & $88.44(6.75)$ & $88.29(6.93)$ \\
Skor Perilaku Gizi dan Hidrasi & $75.77(12.68)^{*}$ & $81.33(10.25)$ \\
\hline
\end{tabular}

Tabel 3. Analisis Hubungan Faktor-faktor yang Mempengaruhi Kejadian Konstipasi

\begin{tabular}{|c|c|c|}
\hline Variabel & Koefisien Korelasi & p-value \\
\hline Umur Ibu (tahun) & 0.242 & 0.015 \\
\hline Umur Kehamilan (bulan) & 0.104 & 0.305 \\
\hline Berat Badan Sebelum Hamil (kg) & 0.030 & 0.765 \\
\hline Lingkar Lengan Atas $(\mathrm{cm})$ & 0.048 & 0.632 \\
\hline Tinggi Badan $(\mathrm{cm})$ & 0.077 & 0.445 \\
\hline Hemoglobin (mg/dl) & 0.032 & 0.750 \\
\hline Skor Pengetahuan & 0.180 & 0.074 \\
\hline Skor Sikap Gizi dan Hidrasi & 0.018 & 0.862 \\
\hline Skor Perilaku Gizi dan Hidrasi & -0.206 & 0.039 \\
\hline
\end{tabular}




\section{Analisis Hubungan Faktor-faktor Mempengaruhi Kejadian Konstipasi}

Analisis inferensial dari faktor-faktor yang mempengaruhi kejadian konstipasi menunjukkan ada hubungan terbalik antara umur ibu dan kejadian konstipasi, dengan koefisien korelasi 0.242 dan $p$-value 0.015. Hal ini menunjukkan bahwa semakin bertambah usia ibu maka semakin tidak mengalami konstipasi selama kehamilan. Selain, umur ibu, perilaku gizi dan hidrasi juga menunjukkan hubungan terbalik yang signifikan dengan kejadian konstipasi (koefisien korelasi -0.206 dan p-value 0.039) (Tabel 3).

\section{PEMBAHASAN}

Penelitian ini merupakan penelitian pertama yang dirancang untuk mengevaluasi faktor-faktor determinan kejadian konstipasi pada ibu hamil di wilayah Kebon Jeruk, Kota Jakarta Barat. Konstipasi dipengaruhi banyak faktor. Ketika konstipasi tidak disebabkan kondisi anatomis atau fisiologis, maka konstipasi yang terjadi disebut konstipasi fungsional. Pada penelitian ini menunjukkan bahwa sebesar $30 \%$ responden mengalami konstipasi fungsional. Penemuan ini juga sejalan dengan penelitian Zhao bahwa lebih dari 30\% wanita mengalami konstipasi selama hamil. ${ }^{11}$ Prevalensi konstipasi ini juga relatif tinggi jika dibandingkan dengan populasi umum. ${ }^{4}$ Kehamilan adalah fase yang sangat penting untuk wanita. Terjadi perubahan fisiologi, biokimia dan pola makan selama hamil. Tubuh mensekresi progesterone dalam jumlah besar sehingga menurunkan fungsi otot dan pergerakan dari sistem pencernaan. ${ }^{3}$ Pada saat hamil keluhan dari sistem pencernaan tidak sebatas mual, muntah dan heartburn namun juga konstipasi dan inkontinensi feses. ${ }^{7}$ Banyak wanita hamil yang cenderung beristirahat sepanjang waktu, yang mana memicu berkurangnya aktivitas sistem pencernaan dan memicu pendarahan serta konstipasi. ${ }^{17}$

Beberapa tahun terakhir, peningkatan stress, taraf pendidikan dan status sosial telah memicu wanita usia subur untuk menunda memiliki anak hingga hampir melebihi usia 35 tahun atau lebih. Ketika memasuki usia lebih dari 35 tahun, maka kehamilan yang dialami membutuhkan banyak perhatian karena terjadinya penurunan pelvis dan ligament, berisiko terkena diabetes gestasional, hipertensi, keguguran dan komplikasi lainnya. ${ }^{18}$ Wanita yang lebih tua memiliki stress emosional yang lebih tinggi dibandingkan wanita yang lebih muda saat hamil. ${ }^{18}$ Stress emosional mampu meningkatkan risiko konstipasi. ${ }^{26}$ Pada penelitian ini menunjukkan bahwa usia yang lebih tua menunjukkan risiko konstipasi lebih rendah. Hal ini bisa disebabkan karena pada kelompok yang tidak mengalami konstipasi memiliki skor pengetahuan, sikap, dan perilaku gizi dan hidrasi yang lebih tinggi bila dibandingkan dengan kelompok yang mengalami konstipasi. Pada kuesioner praktik gizi dan hidrasi menanyakan terkait apakah responden memenuhi kebutuhan cairan dalam sehari, apakah ketika mual dan muntah berusaha untuk memenuhi kebutuhan cairan dengan minum agar tidak kekurangan cairan tubuh, apakah responden mengonsumsi makanan yang lengkap (makanan pokok, protein hewani, protein nabati, sayur dan buah) untuk memenuhi kebutuhan gizi, apakah responden mengonsumsi buah dan sayur agar tidak sembelit dan apakah responden mengonsumsi susu setiap hari. Responden yang tidak mengalami konstipasi memiliki skor yang tinggi pada aspek praktek gizi dan hidrasi. Selain itu, usia tidak mempengaruhi kejadian konstipasi karena rata-rata usia wanita hamil tidak terlalu tua yaitu dibawah 30 tahun. Banyak penelitian menyebutkan bahwa risiko konstipasi meningkat seiring usia. Namun, usia yang dimaksud adalah usia lanjut dimana seseorang cenderung menderita penyakit kronis yang meningkatkan risiko konstipasi. ${ }^{27}$

Dibandingkan dengan usia, konstipasi dan pola makan sangat erat kaitannya. Pada penelitian ini, kami mengukur secara kualitatif bagaimana mengkonsumsi cairan, makanan yang mengandung karbohidrat, lemak, protein nabati dan hewani serta sayur dan buah. Perilaku gizi dan hidrasi ibu hamil menunjukkan hubungan berkebalikan yang signifikan dengan kejadian konstipasi. Hal ini sejalan dengan penelitian lain bahwa konsumsi sumber serat yang rendah sering kali menjadi penyebab terjadinya konstipasi. Pola makan ibu hamil tidak memenuhi gizi seimbang jika mengonsumsi tinggi protein dan lemak saja. Ibu hamil disarankan mengonsumsi sumber serat dari sayur dan buah. ${ }^{17,18}$ Penelitian lain juga menjelaskan bahwa responden yang mengalami konstipasi mengonsumsi cairan yang lebih rendah jika dibandingkan dengan responden yang tidak mengalami konstipasi. ${ }^{4,19}$ Serat meningkatkan berat feses dan konsumsi air membuat feses keras dan mengurangi berat feses yang memicu konstipasi. ${ }^{28}$

Data biokimia yang kami temukan juga menunjukkan tidak ada hubungan dengan konstipasi. Hal ini dikarenakan ibu hamil memiliki serum hemoglobin yang suboptimal. Sejauh ini memang tidak ada hubungan antara kadar haemoglobin dan konstipasi kecuali jika ibu hamil mengonsumsi tablet Fe. Namun, kami tidak menginvestigasi lebih jauh konsumsi tablet $\mathrm{Fe}$ ibu hamil. ${ }^{19}$ Kami menduga bahwa konstipasi yang dialami ibu hamil di wilayah penelitian kami lebih dikarenakan oleh pengetahun, sikap dan perilaku gizi dan hidrasi.

\section{SIMPULAN}

Prevalensi konstipasi pada penelitian kami sebesar $30 \%$. Penelitian kami menunjukkan secara signifikan ada hubungan berkebalikan antara perilaku gizi dan hidrasi terhadap status konstipasi. Semakin baik perilaku gizi dan hidrasi maka semakin tidak berhubungan dengan 
konstipasi. Konsumsi kelompok makanan yang lengkap seperti makanan pokok, protein hewani, protein nabati, sayur dan buah serta cairan mampu mencukupi kebutuhan tubuh akan zat gizi terutama serat sehingga mampu mencegah terjadinya konstipasi selama kehamilan.

\section{UCAPAN TERIMA KASIH}

Terima kasih kepada Dikti yang telah membiayai penelitian Model KIE pada Pencegahan Hipohidrasi Kehamilan oleh Dr. Erry Yudhya Mulyani.

\section{DAFTAR PUSTAKA}

1. Wuhan J. Gastrointestinal Motility Group of Digestive Disease Branch and Colorectal Group of Surgery Branch of Chinese Medical Association. Chinese Guideline for Chronic Constipation. Chin J Dig. 2013;33(5):291-7.

2. Kassolik K, Waldemar A, Iwona W, Marcin B, Kamila V, Ewa J-K, Barbara N, Donata K. The Effectiveness of Massage Based on The Tensegrity Principle Compared with Classical Abdominal Massage Performed on Pattient with Constipation. Arch Gerontol Geriat. 2015;61(2):202-11.

3. Verghese TS, Futaba K, Latthe P. Constipation in pregnancy. Obstet Gynaecol. 2015;17(2):111-5.

4. Derbyshire E, Davies J, Costarelli V, Dettmar P. Diet, physical inactivity and the prevalence of constipation throughout and after pregnancy. Matern Child Nutr. 2006;(2):127-34.

5. Belsey J, Greenfield S, Candy D, Geraint M. Systematic review: impact of constipation on quality of life in adults and children. Aliment Pharm Ther. 2010;31(9):938-49.

6. Bharucha AE, Dorn SD, Lembo A, Pressman A. American Gastroenterological Association medical position statement on constipation. Gastroenterology. 2013;144(1):211-7.

7. Shin GH, Toto EL, Schey R. Pregnancy and postpartum bowel changes: constipation and fecal incontinence. Am.

Gastroenterol. 2015;110(4):521-9.

8. Chinzon D, Dias-Bastos TR., Medeiros da Silva A., Eisig JN, Latorre MDRDDO. Epidemiology of constipation in Sao Paulo, Brazil: a populationbased study. Curr. Med. Res. Opin. 2015;31(1):5764.

9. Mugie SM, Benninga MA, Di Lorenzo C. Epidemiology of constipation in children and adults: a systematic review. Best Pract Res $\mathrm{Cl}$ Ga. 2011;25(1):3-18.

10. Kaboli SA, Pourhoseingholi MA, MoghimiDehkordi B, Safaee A, Habibi M, Pourhoseingholi A, Vahedi M. Factors associated with functional constipation in Iranian adults: a population-based study. Gastroenterol Hepatol Bed Bench. 2010;3(2).

11. Zhao YF, Ma XQ, Wang R, Yan XY, Li ZS, Zou DW, et al. Epidemiology of functional constipation and comparison with constipation-predominant irritable bowel syndrome: the Systematic Investigation of Gastrointestinal Diseases in China (SILC). Aliment Pharmacol Ther. 2011;34(8):1020-9.

12. Liu W, Liu XH, Fang XC, Zhou LK, Yang XL, Ke MY, et al. A Multicenter Epidemiological Investigation On Outpatients with Chronic Constipation in Beijing Area. Chin J Gastroenterol. 2010;15(2):95-8.

13. You JS, Park JY, Chang KJ. A case-control study on the dietary taurine intake, nutrient status and life stress of functional constipation patients in Korean male college students. J Biomed Sci. 2010;17:S141.

14. Devanarayana NM, Rajindrajith S. Association between constipation and stressful life events in a cohort of Sri Lankan children and adolescents. J Trop Pediatr. 2010;56(3):144-8.

15. Kil SY, Oh WO, Koo BJ, Suk MH. Relationship between depression and health-related quality of life in older Korean patients with chronic obstructive pulmonary disease. J Clin Nurs. 2010;19(9-10):1307-14.

16. Cheng C, Chan AO, Hui WM, Lam SK. Coping strategies, illness perception, anxiety and depression of patients with idiopathic constipation: a population-based study. Aliment Pharmacol Ther. 2003;18(3):319-26.

17. Wald A. Constipation, diarrhea and symptomatic hemorrhoids during pregnancy. Gastroenterol Clin N. 2003;32(1):309-22.

18. Shi W, Xu X, Zhang Y, Guo S, Wang J,Wang J. Epidemiology and risk factors of functional constipation in pregnant women. PloS One. 2015;10(7).

19. Riza N. Hubungan Konsumsi Serat, Air, Tablet Fe Dan Aktivitas Fisik Dengan Kejadian Konstipasi Pada Ibu Hamil Di Wilayah Kerja Puskesmas Lubuk Buaya Kota Padang Tahun 2017. [Doctoral dissertation]. Padang: Universitas Andalas; 2017.

20. Hayati S. Pengaruh Konsumsi Tablet Fe Dengan Kejadian Konstipasi Pada Ibu Hamil Diwilayah Kerja Puskesmas Payung Sekaki Pekanbaru. Jurnal Medika Usada. 2020;3(1):15-9

21. Purbadewi L, Ulvie YNS. Hubungan Tingkat Pengetahuan Tentang Anemia Dengan Kejadian Anemia Pada Ibu Hamil. Jurnal Gizi. 2013;2(1).

22. Goni AP, Laoh JM, Pangemanan DH. Hubungan Pengetahuan Dan Sikap Ibu Hamil Dengan Status 
Gizi Selama Kehamilan Di Puskesmas Bahu Kota Manado. Jurnal Keperawatan. 2013;1(1).

23. Mulyani EY, Briawan D, Santoso BI. Hydration Status Of Pregnant Women In West Jakarta. Asia Pac. J. Clin. Nutr.. 2017;26:S26.

24. Longstreth GF, Thompson WG, Chey WD, Houghton LA, Mearin F, Spiller RC. Functional bowel disorders. Gastroenterology. 2006;130(5):1480-91.

25. Vazquez JC. Constipation, haemorrhoids, and heartburn in pregnancy. BMJ clinical evidence. 2010 .
26. Yamada M, Sekine M, Tatsuse T. Psychological stress, family environment, and constipation in japanese children: The Toyama birth cohort study. Journal of epidemiology. 2018;JE20180016

27. Harari D. Constipation and fecal incontinence in old age. In Brocklehurst's Textbook of Geriatric Medicine and Gerontology. WB Saunders. 2010:909-25

28. Jangid V, Godhia M, Sanwalka N, Shukla A. Water Intake, Dietary Fibre, Defecatory Habits and its Association with Chronic Functional Constipation. Curr Res Nutr Food Sci. 2016;4(2),90-5. 